\title{
Serum Lactate Dehydrogenase Activity and Its Correlation with Carbohydrate Intake in Advanced Lung Cancer Patients
}

Received, 28 September 2018 Accepted, 10 December 2018

Link to DOI:

10.25220/WNJ.V02.i2.0002

Journal Website:

www.worldnutrijournal.org

\author{
Claresta Diella ${ }^{1}$, Ninik Mudjihartini ${ }^{2}$, Diana Sunardi $^{3}$, Dian Novita Chandra $^{3}$, Yulhasri $^{2}$, Achmad \\ Mulawarman Jayusman ${ }^{4}$ \\ 1. Department of Nutrition, Faculty of Medicine, Universitas Indonesia, Jakarta, Indonesia \\ 2. Department of Biochemistry and Molecular Biology, Faculty of Medicine, Universitas Indonesia, \\ Jakarta, Indonesia \\ 3. Department of Nutrition, Cipto Mangunkusumo National General Hospital, Faculty of Medicine, \\ Universitas Indonesia, Jakarta, Indonesia \\ 4. Pulmonology Department, Dharmais National Cancer Hospital, Jakarta, Indonesia
}

\begin{abstract}
Introduction This study aims to determine serum lactate dehydrogenase activity and its correlation with carbohydrate intake in advanced lung cancer patients at Dharmais National Cancer Hospital Jakarta. Anaerobic glycolysis is increased in cancer cells, termed the Warburg effect. This results in lactate as an end product, catalysed by LDH enzyme. Activities of lactate in cancer influence tumor growth initiation, survival, proliferation, angiogenesis and metastasis. Serum LDH activity can be used as a diagnostic, prognostic, and predictive marker for tumor sensitivity and resistance to therapy.

Methods A total of 56 advanced lung cancer patients from Dharmais National Cancer Hospital Jakarta were included in this cross sectional study. Subjects were recruited by consecutive sampling. Food intake of total carbohydrate was obtained using 24 hours food recall method. The activity of serum LDH (IU/L) was measured by using enzymatic spectrophotometry method in automated analyzer.

Results The mean of age subjects was $56.98 \pm 10.36$ years old and $55.4 \%$ were male. Carbohydrate intake based on 24 hours food recall was $57.64 \pm 10,85 \%$. The median of LDH activity was 54.5 (1646539 ) IU/L, with $60.7 \%$ increased. This study showed medium negative significant correlation $(p=$ $0.017, r=-0.317$ ) between total carbohydrate intake per day in grams with LDH serum activity.

Conclusion If carbohydrate source is reduced, the LDH enzyme will increase to keep the glycolysis process going. The results of this study showed adequate carbohydrate is needed in patients with cancer.
\end{abstract}

Keywords lactate dehydrogenase, lung cancer, carbohydrate intake

\section{Introduction}

Cancer is one of the major causes of morbidity and mortality in the world. According to the Global Burden of Cancer (GLOBOCAN) data in 2012,

\footnotetext{
Corresponding author:

Claresta Diella, MD

Department of Nutrition, Faculty of Medicine,

Universitas Indonesia

Salemba Raya 6, Central Jakarta

Email: rafaelaclarestadiella@gmail.com
}

lung cancer has the highest incidence rate and is the leading cause of death in men. ${ }^{1}$ Lung cancer is one of the three most common cancer types in Dharmais Cancer Hospital during year 2010-2013. ${ }^{2}$ Lung cancer patients have poor prognosis and $85 \%$ of patients are diagnosed at an advanced stage. ${ }^{3}$

There is an altered energy metabolism and mitochondrial respiration in cancer cells. Carbohydrate metabolism changes in cancer cells is an increased anaerobic glycolysis rate which 
converts pyruvate to lactate even in oxygenated conditions, known as the Warburg effect. Conversion of pyruvate to lactate in cancer cells is catalyzed by lactate dehydrogenase (LDH) enzyme. ${ }^{4}$ This enzyme is scattered in various tissues and its level in the blood increases in several diseases including malignancy. ${ }^{5}$ The roles of LDH in cancer cells including the initiation of tumor growth, maintaining cancer cell survival, progression, and metastasis. LDH activities can become a marker to identify different types of malignancy and as a prognostic marker to determine the survival of cancer patients. ${ }^{6}$

The aim of this study was to determine serum lactate dehydrogenase (LDH) activity and its correlation with carbohydrate intake in advanced lung cancer patients. Previous research by Amanda et al. ${ }^{7}$ in 49 lung cancer patients at Dharmais Cancer Hospital reported $53.1 \%$ of subjects showed total energy intake below ESPEN recommendation, $75.5 \%$ of subjects were in sufficient carbohydrate intake with $30.6 \%$ subjects were in sufficient simple carbohydrate intake. Yoshimura et al. ${ }^{8}$ research in healthy subjects obtained a negative correlation between the percentage of LDH isoenzymes with protein and fat intake. Research by Klement and Swenney in six cancer patients given ketogenic diet (carbohydrate $<50$ grams per day), get the result of tumor regression and tumor growth deceleration. Thus, modification of carbohydrate intake may affect tumor development associated with patient prognosis and survival. ${ }^{9}$

Research about the effect of nutritional intake with the development of cancer cells is still limited. There has been no research on the correlation between carbohydrate intake to LDH activity. It is expected to know the correlation between serum LDH activity with carbohydrate intake in lung cancer patients to support nutritional management in cancer patients from this research.

\section{Methods}

\section{Subjects and study design}

A cross sectional study was conducted to patients with advanced lung cancer at Dharmais National Center Hospital Jakarta from March 2018 to May 2018 using consecutive sampling method. The minimal estimation of minimum sample size was calculated using the formula for correlation study by taking $\alpha=0.05, \beta=0.20$, and $\mathrm{r}=0.4$ with $20 \%$ addition, thus a total number 57 subjects were required. The study was approved by the committee of the Medical Research Ethics of the Dharmais Cancer Hospital. All patients enrollments were voluntary and with informed consent.

Inclusion criteria were men and women age 18 years old, diagnosed with primary lung cancer, any stadium, and currently not receiving any therapy. Subject who had diabetes mellitus, end stage chronic kidney disease, chronic liver disease, cardiovascular disease, tuberculosis, pregnant, any bacterial infection, and trauma were excluded from this study.

\section{Data collection}

Interviews were conducted to determine characteristic of the subject. Histopathology and cancer stadium data were determined from the medical record. Food intake of total energy and total carbohydrate were obtained using 24 hours food recall method. Anthropometric measurements including weight, height and body mass index (BMI). Weight was measured using SECA $^{\circledR}$ electrodigital scale, height with Microtoise Stature Meter, and BMI was categorized into five groups according to the Asian Pacific criteria of BMI. Serum activity of LDH (IU/L) were measured with an enzymatic spectrophotometry method in automated analyzer (Roche Cobas $6000 \mathrm{C} 501$ ). ${ }^{10} \mathrm{~A}$ high LDH value was defined as $\geq 480$ IU/L. ${ }^{11}$

\section{Statistical analysis}

Data were analyzed using the Statistical Package for the Social Sciences (SPSS) version 20 for Windows. The normality of data distribution was analyzed using Kolmogorov-Smirnov. If $p<0.05$ data were normal distributed and were presented in mean \pm standard deviation. If it is not normal, data are presented in median and minimum-maximum range of values. The correlation of carbohydrate intake with LDH activity serum were analyzed by Spearman Rank correlation test.

\section{Results}

\section{Subject characteristic}

Based on the inclusion and exclusion criteria, 60 subjects were willing to take part in this study and signed an informed consent. In blood sampling collection, there were 4 subjects who refused. 
Total subjects who followed this study and whose data could be analyzed was 56 subjects. From this study, the average age of subjects was $56.98 \pm 10.36$ years. A total of $55.4 \%$ subjects were male. From the pathology results, it was revealed that all subjects had non-small cell carcinoma types: $78.6 \%$ were adenocarcinoma and $21.4 \%$ were squamous carcinoma. Based on cancer stage, $96.4 \%$ of subjects were in stage IV and $3.6 \%$ were in stage III-B. The average value of subjects' BMI was $20.59 \pm 3.86$ $\mathrm{kg} / \mathrm{m}^{2}$ and $39.3 \%$ were in normal range of BMI. These results are shown in Table 1 .
Characteristic distribution based on energy and carbohydrate intake

The median value of total energy intake measured by 24 hours food recall method was 1459.25 (425.9$2205.9) \mathrm{kcal}$ (Table 2). From the analysis, $64.3 \%$ of subjects had low level of energy intake. Carbohydrate intake to total energy was in a good amount (64.3\%).

Characteristics distribution based on LDH serum activity

The median value of LDH serum activity was 541.5 (164-6539) IU/L. There were 34 subjects $(63 \%)$ had LDH serum value above 480 IU/L. The

Table 1. Characteristic of subjects $(n=56)$

\begin{tabular}{ll}
\hline Characteristic & Results \\
\hline Age, (year) & $56.98 \pm 10.36^{*}$ \\
Sex, $\mathrm{n}(\%)$ & $31(55.4)$ \\
Men & $25(44.6)$ \\
Women & \\
Education, n (\%) & $17(30.4)$ \\
Low & $28(50)$ \\
Middle & $11(19.6)$ \\
High & \\
Histopathology, n (\%) & $56(100)$ \\
Non small cell lung carcinoma & $44(78.6)$ \\
Adenocarcinoma & $12(21.4)$ \\
Squamous cell carcinoma & $0(0)$ \\
Large cell carcinoma & $0(0)$ \\
Small cell lung carcinoma & \\
Stage, $\mathrm{n}(\%)$ & $2(3.6)$ \\
Stage III-B & $54(96.4)$ \\
Stage IV & \\
Anthropometric & $50(35-78)$ \\
Weight (kg) & $160.06 \pm 7.54$ \\
Height (cm) & $20.59 \pm 3.86$ \\
Body mass index $\left(\mathrm{kg} / \mathrm{m}^{2}\right)$ & \\
Body mass index classification, $\mathrm{n}(\%)$ & $18(32.1)$ \\
Underweight & $22(39.3)$ \\
Normal & $9(16.1)$ \\
Overweight & $7(12.5)$ \\
Obese 1 & $0(0)$ \\
Obese 2 &
\end{tabular}


Table 2. Characteristics distribution based on energy and carbohydrate intake $(n=56)$

\begin{tabular}{ll}
\hline & Results \\
Variable & 24 hours food recall \\
\hline Total energy intake per day $(\mathrm{kcal})$ & $1459.25(425.9-2205.9)$ \\
Low, $\mathrm{n}(\%)$ & $36(64.3)$ \\
Average, $\mathrm{n}(\%)$ & $20(35.7)$ \\
& \\
Total carbohydrate intake per day $(\mathrm{g})$ & $202.54 \pm 91.53$ \\
Total carbohydrate of total energy, $(\%)$ & $57.64 \pm 10.85$ \\
Low, $\mathrm{n}(\%)$ & $7(12.5)$ \\
Average, $\mathrm{n}(\%)$ & $36(64.3)$ \\
High, $\mathrm{n}(\%)$ & $13(23.2)$ \\
\hline
\end{tabular}

characteristic of subjects based on their LDH serum activity is shown in Table 3.

The correlation between carbohydrate intake and LDH serum activity

This research revealed a medium negative correlation ( $p=0.017, r=-0.317)$ between LDH serum activity and total carbohydrate intake per day (in grams) based on 24 hours food recall (Table 4). No significant correlation was found between $\mathrm{LDH}$ serum activity and carbohydrate intake of total energy. lung cancer is the most common type of cancer affecting males in Indonesia. ${ }^{12}$

This study shows the average age of the subjects was $56.98 \pm 10.36$ years old. The data is consistent with the Riskesdas data in 2013. ${ }^{13}$ Previous research conducted by Anwar et al. ${ }^{13}$ in lung cancer patients in 2010 - 2011 revealed similar results. Based on the research by Amanda et al. ${ }^{7}$ in lung cancer patients stage IIIB and IV in Dharmais Cancer Hospital in 2107, the average age of subjects was $55.83 \pm 12.62$ years with the majority in the range of 45-65 years, which is also similar to the

Table 3. Characteristics distribution based on LDH serum activity $(\mathrm{n}=56)$

\begin{tabular}{ll}
\hline Variable & Results \\
\hline LDH serum activity (IU/L) & $541.5(164-6539)^{*}$ \\
Normal, n (\%) & $22(39.3)$ \\
High, n (\%) & $34(60.7)$ \\
Stage III-B & \\
$\quad$ Normal, n (\%) & $2(100)$ \\
High, n (\%) & 0 \\
Stage IV & \\
$\quad$ Normal, n (\%) & $20(37)$ \\
High, n (\%) & $34(63)$ \\
\hline
\end{tabular}

\section{Discussion}

A total of $55.4 \%$ of the subjects in this study were male. The results of this study are consistent with GLOBOCAN data in 2012 that lung cancer was the leading cause of death with the highest incidence rate in male. ${ }^{1}$ Data from WHO also mentioned that findings of this research.

Classification of lung cancer can be distinguished into non-small cell lung cancer (NSCLC) and small cell lung cancer (SCLC), with prevalence of $80 \%$ for NSCLC. ${ }^{3}$ All subjects in this research had NSCLC type. 
Table 4 . The correlation between carbohydrate intake with LDH serum activity $(n=56)$

\begin{tabular}{lcc}
\hline Carbohydrate intake & $\begin{array}{c}\text { LDH serum } \\
\mathrm{r}\end{array}$ & $\mathrm{P}$ \\
\hline $\begin{array}{l}\text { Carbohydrate intake per day }(\mathrm{g}) \\
24 \text { hours food recall }\end{array}$ & $-0.317^{+}$ & 0.017 \\
$\begin{array}{l}\text { Carbohydrate intake of total energy (\%) } \\
24 \text { hours food recall }\end{array}$ & $-0.136^{+}$ & 0.316 \\
\hline
\end{tabular}

There were $78.6 \%$ subjects who had adenocarcinoma type. Around $96.4 \%$ subjects were in the stage IV. The result is similar with the research conducted by Anwar et al. ${ }^{13}$ in Persahabatan hospital. Research by Siregar et al. ${ }^{14}$ which was related to lung cancer patients showed $66.6 \%$ of the subjects had adenocarcinoma, while the rest had small cell carcinoma.

Around 39.3\% subjects had normal BMI. Previous research in 2017 at the Dharmais Cancer Hospital showed similar results: $36.7 \%$ and $22.5 \%$ subjects had normal and low BMI, respectively. ${ }^{7}$ Total energy intake based on 24 hours food recall method showed median value of 1425.25 (425.9$2205.9)$ kcal with as much as $64.3 \%$ subjects had low energy intake. Disease and external factors can affect food intake and decreased appetite in cancer patients. Substrates released by cancer cells such as pro-inflammatory cytokines and lactate, metabolic changes, neuro-hormonal changes, cancer types, cancer sites, and cancer pain can affect appetite and food intake. ${ }^{13}$ External factors that can affect food intake and appetite including age, psychosocial, economic, and sociocultural factors. ${ }^{14}$ Research by Solheim et al. ${ }^{15}$ revealed that food intake will decrease along with the increase of age. Family support on assisting patients during treatment as well as motivation from family in nutritional support have impact on appetite and food intake. ${ }^{16}$ Dharmais Cancer Hospital is a national referral hospital thus the patients come from diverse sociocultural backgrounds. This will affect eating habit and appetite of the patient. Type of food, cooking method, and taste differ from patient's eating habit can affect appetite and food intake.

Based on 24 hours food recall, total carbohydrate intake on energy requirement was $57.64 \pm 10.85 \%$, with most subjects having sufficient total carbohydrate intake. Carbohydrates are the main source of energy for the body with a recommended daily intake of $45-65 \%$ of total energy. ${ }^{17}$ Research by Caesandri et al. ${ }^{16}$ in cancer patients showed $80 \%$ of subjects consumed carbohydrates as the main food source.

In this study, $63 \%$ of patients had LDH activity $>480 \mathrm{IU} / \mathrm{L}$. Research by Lee et al. ${ }^{18}$ in NSCLC stage IV patients before therapy revealed similar result. High LDH activity correlates to organ metastatic such as bones, other lung parts, and abdomen. Increased LDH activity in cancer cells correlates with inflammation and tumor necrosis which describe the activity of cancer cells. Various comorbid diseases such as acute heart failure, acute coronary syndrome, severe liver dysfunction, endstage renal disease, and hemolysis can affect the increase of LDH activity. ${ }^{19}$ Study by Wulaningsih et al. ${ }^{20}$ revealed there were an increased LDH activity in patients with blood, colorectal, and lung cancer. It was shown that LDH activity was associated with cancer prognosis. Proliferation of cancer cells requires a lot of energy resulting in increased activity of glycolysis. Higher glycolysis results in the increased LDH activity to convert pyruvate into lactate which is the main ATP component in cancer cells. Increased LDH activity reflects increased lactate in cancer cells. Lactate will come out from cancer cells and affect pathways which cause increased angiogenesis, tumor migration and metastasis, increased resistance to therapy, and decreased immunity. ${ }^{21}$

This study found $65.4 \%$ of stage IV lung cancer subjects had high LDH values. Stage IV of lung cancer illustrates the presence of distant metastases, either to the contralateral lung, nodules in the pleura, malignant pleural effusions, pericardial effusion (stage 4A), or metastases to other organs such as liver, brain, bones or suprarenal (stage 4B). ${ }^{2}$ Research conducted by Hermes et al. ${ }^{19}$ in SCLC patients showed LDH activity was found 
to increase consistently with the number of organs affected.

Medium negative correlation $(\mathrm{r}=-0.317, \mathrm{p}=$ 0.017 ) was found between total carbohydrate intake, based on 24 hours food recall method, with serum LDH activity. Intake analysis using the 24 hours food recall method is widely used in surveillance studies to determine food intake in a population. ${ }^{22}$ Food data from 24 hours recall describes short-term intake. LDH activity increases to supply high glucose needs by catalyzing the change of lactate to pyruvate as gluconeogenesis component. In addition, to supply the need for glucose as the basic ingredient of glycolysis, the intake of external carbohydrates is needed as the main source of glucose. This amount of intake can be analyzed by using 24 hour food recall.

The Warburg effect, which is described as the tendency of cells to get energy in the form of ATP through anaerobic glycolysis process even though in a state of sufficient oxygen, occurs in cancer cells. LDH is an enzyme which converts pyruvate into lactate in the anaerobic glycolysis process. ${ }^{23}$ In cancer cells, most of the lactate is exported out of cells by increasing the expression of monocarboxylate transporters (MCT), which acts as facilitator to transport lactate out of the cell. Continuous formation of lactate in order to obtain ATP occurs due to oncogenes and mutations in tumor suppressors in cancer cells. Furthermore, in cancer cells, there is an increased of HIF-I $\alpha$ transcription factor and c-Myc oncogene, also repressed p53 expression. These increase GLUT (glucose transporter) expression and translocation which then results in increased lactate formation. Expression and activity of glycolytic enzymes, especially LDH isoenzymes LDHA, also escalated due to HIF-I $\alpha, c-M Y C$, and down regulation of p53. Increased isoenzyme LDHA will convert pyruvate to lactate. Moreover, mitochondrial dysfunction as well as upregulation of MCT1 and MCT4 as lactate transporters also increase lactate production in cancer cells. ${ }^{24}$

Increased glycolysis rate to obtain ATP due to oncogenes and mutations of tumor suppressors in cancer cells also causes NAD + depletion. To achieve balance between NADH and NAD+, in order to maintain the glycolysis process, pyruvate will be further converted to lactate by the LDH enzyme. ${ }^{24}$ If the glucose obtained from carbohydrate source is reduced the LDH enzyme will increase in order for the glycolysis process to obtain ATP and maintain the redox balance by converting pyruvate to lactate. High rates of glycolysis lead to decreased glycogen reserves in the liver resulting in increased proteolysis for gluconeogenesis. Chronic proteolysis is one of cancer cachexia pathophysiology of. ${ }^{25}$ If too much glucose is given then it will be used by cancer cells to process anaerobic glycolysis and form ATP by converting pyruvate to lactate. ${ }^{26}$ This is supported by the overexpression of GLUT 1 transporters in cancer cells as the main transporters of glucose. ${ }^{27}$ The high level of lactate in cells stimulates VEGF production which has a role in cell migration and angiogenesis process. Lactate in cancer cells can act as an antioxidant resulting in resistance to chemotherapy and radiation. ${ }^{21}$

The ESPEN recommendation of total energy intake for cancer patients is $25-30$ kcal /bodyweight/day. Inadequate energy intake can cause malnutrition in cancer patients. Adequate energy intake does not affect the growth of cancer cells. Basal energy requirements in patients with lung cancer are higher than other types of cancer. ${ }^{28}$ The mechanism of high basal energy demand in lung cancer is unclear. It may be related to systemic inflammation. ${ }^{29}$

In conclusion, if carbohydrate source is reduced, the LDH enzyme will increase to sustain the glycolysis process. The results of this study showed adequate carbohydrate is needed to improve the quality and life expectancy in lung cancer patients.

This study was the first cross sectional study aiming to find the correlation between carbohydrate intake with LDH activity as one of the determinants of prognosis in lung cancer patients. The advantage of this study was using serum LDH activity biomarkers as one of the prognostic markers in lung cancer patients. In addition, calibrated anthropometry tools were used to measure height and weight. The collection of blood specimens and the analysis of laboratory results were performed by well-trained laboratory personnel and analysts.

Limitation in this study was the utilization of 24 hours food recall method to determine the carbohydrate intake. This method relies on the memory and assumptions of the intake portions by each subject. However, this had been anticipated, thus we used trained personnel and food models to help the subject to remember and estimate the number of foods. 
Further research may be needed using LDHA isoenzymes, which is a more specific LDH markers, to assess carbohydrate metabolism in lung cancer patients.

\section{Conflict of Interest}

None of the other authors have conflict of interest. No educational grant is provided to the rest of authors.

\section{Open Access}

This article is distributed under the terms of the Creative Commons Attribution 4.0 International Licence(http://creativecommons.org/licenses/by/4.0 ), which permits unrestricted use, distribution, and reproduction in any medium, provided you give appropriate credit to the original author(s) and the source, provide a link to the Creative Commons license, and indicate if changes were made.

\section{Acknowledgement}

We would like to express our gratitude to the patients, nurse and all doctors in Dharmais National Cancer Hospital, Jakarta, Indonesia.

\section{References}

1. GLOBOCAN. Estimated cancer incidence, mortality dan prevalence worldwide in 2012, International Agency for Research on Cancer, World Health Organization 2012. Available at: http://globocan.iarc.fr/old/FactSheets/cancers/lu ng-new.asp (accessed 2017 Sept 13)

2. Komite Nasional Penanggulangan Kanker (KPKN). Panduan nasional penanganan kanker paru. Kementrian Kesehatan Republik Indonesia. 2105. Available at : http://kanker.kemkes.go.id/ (accessed 2017 Sept 12)

3. Cruz, C.S. Dela, Tanoue LT, Matthay RA. Lung cancer: epidemiology, etiology, and prevention. Clin Chest Med 2011;32(4):1-61. [Google Scholar]

4. Doherty JR, Cleveland JL. Targeting lactate metabolism for cancer therapeutics. J Clin Invest 2013;123(9):3685-92. [Google Scholar]

5. Agrawal A, Gandhe MB, Gupta D, Reddy MVR. Preliminary Study on Serum Lactate Dehydrogenase (LDH)-Prognostic Biomarker in Carcinoma Breast. J Clin Diagn Res JCDR 2016;10(3). [Google Scholar]
6. Verma A, Phua CK, Sim WY, Algoso RE, Tee KS, Lew SJW, et al. Pleural LDH as a prognostic marker in adenocarcinoma lung with malignant pleural effusion. Medicine. 2016;95(26):e3996.

7. Amanda P, Sunardi D, Sutandyo N. Correlation between carbohydrate, protein and fat intake with serum c-reactive protein level in lung cancer patients stage IIIB-IV. World Nutr J 2018;1(2):31-7. [Google Scholar]

8. Yoshimura T, Miyoshi T, Imaki M, Tamura T, Fujii M, Hori Y, et al. Effect of high carbohydrate diet on serum lactate dehydrogenase isozyme pattern in Japanese young men. Acta Biol Hung 1986;37(3-4):2438. [Google Scholar]

9. Klement RJ, Sweeney RA. Impact of a ketogenic diet intervention during radiotherapy on body composition: I. Initial clinical experience with six prospectively studied patients. BMC Res Notes 2016;9(143):1-13. [Google Scholar]

10. Groussard C, Morel I, Chevanne M, Monnier M, Cillard J, Delamarche A. Free radical scavenging and antioxidant effects of lactate ion: an in vitro study. J Appl Physiol Bethesda Md 2000;89(1):169-75. [Google Scholar]

11. Zumárraga JP, Am B, Rosa LPDL, Caiero MT, Camargo OPD. Serum values of alkaline phospatase and lactate dehydrogenase in osteosarcoma. Acta Ortop Bras 2016;24(3):1426. [Google Scholar]

12. WHO. Cancer. February 2017. Available at : http://www.who.int/mediacentre/factsheets/fs29 7/en/ (accessed 2017 Sept 13)

13. Anwar A, Syahruddin E, Aniwidyaningsih W, Widyahening IS, Susanto AD. The causes of death analysis in lung cancer patient. J Respir Indo 2014;34:11-6. [Google Scholar]

14. Siregar YS, Widyaningsih W, Syahruddin E. Indeks Massa Tubuh, Persentase Otot Rangka dan Albumin pada Pasien Kanker Paru Karsinoma Bukan Sel Kecil Sebelum dan Setelah Kemoterapi. JRI 2016;36(2):73-82. [Google Scholar]

15. Solheim TS, Blum D, Fayers PM, Hjermstad MJ, Stene GB, Strasser F. Weight loss, appetite loss and food intake in cancer patients with cancer cachexia: Three peas in a pod? - analysis from a multicenter cross sectional study. Acta Oncol 2014;53(4):539-46. [Google Scholar]

16. Caesandri SDP, Adiningsih S. Peranan dukungan pendamping dan kebiasaan makan pasien kanker selama menjalani terapi. Media Gizi Indonesia 2015:10(2). Available at :https://e- 
journal.unair.ac.id/MGI/article/view/3376 (accessed 2018 May)

17. Ross CA, Caballero B, Cousins RJ, Tucker KL, Zieger TR. Modern Nutrition in health and disease. 7th edition. Wolters Kluwer. Lippincot William\&WIlkins; 2014.pg 36-57.

18. Lee DS, Park KR, Kim SJ, Chung MJ, Lee YH, Chang JH. Serum lactate dehydrogenase levels at presentation in stage IV non-small cell lung cancer: predictive value of metastases and relation to survival outcomes. Tumor Biol 2016;37(1):619-25. [Google Scholar]

19. Hermes A, Gatzemeier U, Waschki B, Reck M. Lactate dehydrogenase as prognostic factor in limited and extensive disease stage small cell lung cancer - A retrospective single institution analysis. Respir Med 2010;104(12):1937-42. [Google Scholar]

20. Wulaningsih W, Holmberg L, Garmo H, Malmstrom H, Lambe M, Hammar N. Serum lactate dehydrogenase and survival following cancer diagnosis. $\mathrm{Br} \mathrm{J}$ Cancer 2015;113(9):1389-96. [Google Scholar]

21. Hirschhaeuser F, Sattler UGA, Mueller-Klieser W. Lactate: A metabolic key player in cancer. Cancer Res 2011;71(22):6921-5. [Google Scholar]

22. Naska A, Lagiou A, Lagiou P. Dietary assessment methods in epidemiological research: current state of the art and future prospects. F1000Research 2017;6:1-8. [Google Scholar]
23. Multhoff G, Molls M, Radons J. Chronic inflammation in cancer development. Front Immunol 2012;2(98):1-17. [Google Scholar]

24. Chaiyasit K, Jularattanaporn V, Muangsri K. Cancer cachexia and metabolism:a challenge in nutrition oncology. JAASP 2012;1(4):187-93. [Google Scholar]

25. San-Millán I, Brooks GA. Reexamining cancer metabolism: lactate production for carcinogenesis could be the purpose and explanation of the Warburg Effect. Carcinogenesis 2017;38(2):119-33. [Google Scholar]

26. Allen BG, Bhatia SK, Anderson CM, Eichenberger-Gilmore JM, Sibenaller ZA, Mapuskar KA. Ketogenic diets as an adjuvant cancer therapy: History and potential mechanism. Redox Biol 2014;2:963-70. [Google Scholar]

27. Tan Z, Yang C, Zhang X, Zheng P, Shen W. Expression of glucose transporter 1 and prognosis in non-small cell lung cancer: a pooled analysis of 1665 patients. Oncotarget 2017;8(37):60954-61. [Google Scholar]

28. Arends J, Bachmann P, Baracos V, Barthelemy $\mathrm{N}$, Bertz H, Bozzetti F. ESPEN guidelines on nutrition in cancer patients. Clin Nutr 2017;36(1):11-48. [Google Scholar]

29. Melkonian SC, Daniel CR, Ye Y, Pierzynski JA, Roth JA, Wu X. Glycemic index, glycemic load, and lung cancer risk in non-hispanic whites. Cancer Epidemiol Biomark Prev Publ Am Assoc Cancer Res Cosponsored Am Soc Prev Oncol 2016;25(3):532-9. [Google Scholar] 